\title{
Polyphenolic and enzymatic characterization of ageing and rejuvenation of hybrid walnut trees (Juglans nigra $x$ Juglans regia): relationship to growth
}

\author{
C. Jay-Allemand ${ }^{1}$, A. Drouet ${ }^{2}$, A. Ouaras ${ }^{2}$ and D. Cornu ${ }^{1}$ \\ 1 Station d'Amélioration des Arbres Forestiers, INRA, Ardon 45160 Olivet, and \\ 2 Laboratoire de Physiologie du Vieillissement et de la Sénescence des Végétaux Supérieurs, Uni- \\ versité d'Orléans, BP 6749, 45067 Orléans Cedex 02, France
}

\section{Introduction}

This paper is mainly devoted to the polyphenolic and enzymatic characterization of hybrid walnut rejuvenation in order to find better plant materials, treatments and conditions which are propitious to propagation. Consequently, a comparative study of adult and rejuvenated annual shoots was undertaken.

Rejuvenation, widely linked to vegetative propagation, was described by Bonga (1982) and it has been shown on hybrid walnut that the propagation success by in vitro culture of cuttings was strongly dependent upon severe annual coppicing (Cornu, 1977). First results with phenolic compounds and enzymes were obtained during the annual growth of walnut: 1) juvenility and rejuvenation seemed to be linked to high values of the ratio of typical polyphenols during the first stages of growth after bud burst (Jay-Allemand et al., 1987; 1988); 2) enzyme activity changes were found between adult and rejuvenated shoots, while no difference was noted in the total protein content (Drouet et al., 1989).
Key results and a brief discussion on different factors involved in walnut ageing and rejuvenation will be presented.

\section{Materials and Methods}

Two clones of hybirid walnut (Juglans nigra $\times \mathrm{J}$. regia), which were grown in a nursery in Orleans, were used. Each clone was represented by 2 different physiological situations: 1) a rejuvenated $13 \mathrm{yr}$ old tree obtained by annual coppicing in March for $10 \mathrm{yr}$, each stump producing at least 60 sprouts; 2) $10 \mathrm{yr}$ old adult form obtained from a cutting of a previous stump sprout.

A detailed study of growth was undertaken to ensure that samples were shoots at the same growth stage and to study the relationship between growth rate and biochemical factors. For each sample, 5 shoots were cut, defoliated and immediately immersed in liquid nitrogen for subsequent lyophilization. Samples were taken on 5 days during shoot elongation $(10,18$ and 24 June; 2 July and 7 August) (Drouet et al., 1989). Extraction, purification and high performance liquid chromatography (HPLC) methods were reported by Jay-Allemand et al. (1988) and enzyme analyses were described by Drouet et al. (1989). 


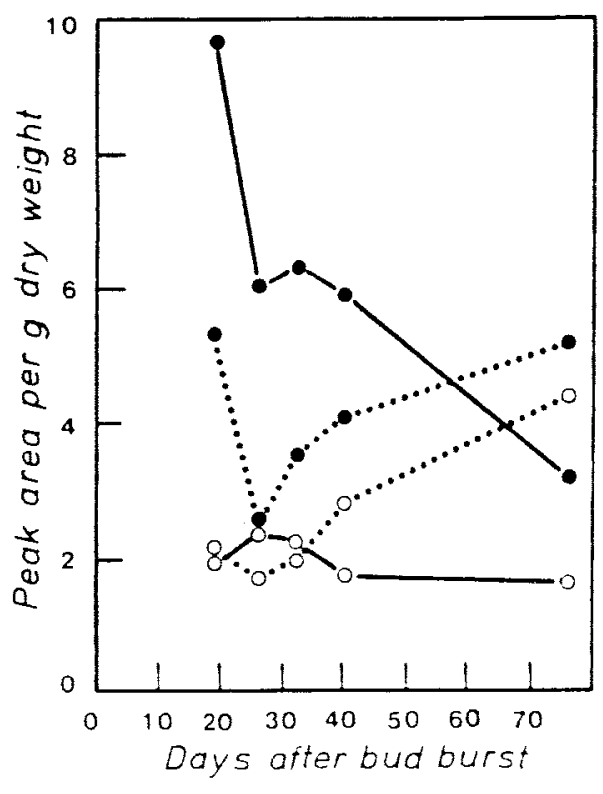

Fig. 1. Evolution of 2 phenolic compounds $A(\bullet)$ and $B$ (o) of adult $(\cdots)$ and rejuvenated $(-)$ shoots of the hybrid walnut $J$. nigra $\times J$. regia 34 . Quantitative data

\section{Results}

Phenolic compounds and phenylalanine ammonia lyase (PAL)

Results on polyphenols are based on 2 main compounds ( $A$ and $B$ ), elucidated by a previous study using canonical discriminant analysis (Jay-Allemand et al., 1988). The evolution of these compounds during elongation of adult and rejuvenation shoots is described in Fig. 1. A high level of compound A (undetermined structure) at the beginning of growth characterized rejuvenated shoots, while adult shoots were characterized by late accumulation of compound $\mathrm{B}$ (flavonol). Moreover, the ratio $A / B$ was always higher in rejuvenated shoots than in adult shoots. These results confirm and specify previous data. On the other hand, during the first growth wave, rejuvenation was marked by 2 PAL peaks which were absent in adult shoots (Fig. 2). However, no simple relationship has been found between this enzyme activity and the accumulation of studied polyphenols.

Enzymes: L-glutamate:NAD+ oxidoreductase (GDH) and D-glucose-6-phosphate:NADP+ oxidoreductase (G6PDH)

The evolution of the 2 enzyme activities in rejuvenated and adult shoots is presented in Fig. 3. Ageing induced an accelerated and asynchronous functioning of these 2 enzymes. While GDH decreased steadily after bud burst. G6PDH activity increased during the first $20 \mathrm{~d}$. On the contrary, the rejuvenation treatment induced both a late (40 d) and synchronous increase of these 2 enzyme activities.

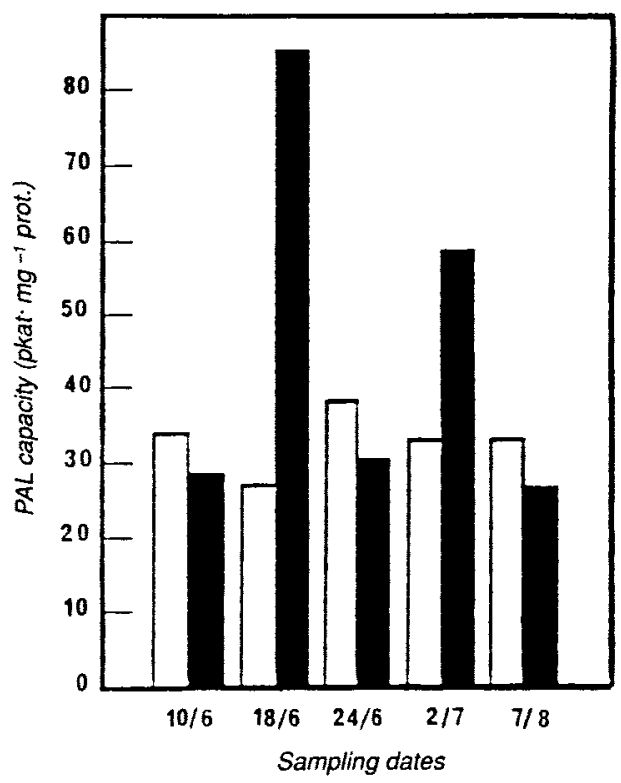

Fig. 2. PAL capacity of adult ( $\square$ ) and rejuvenated ( $\square$ ) shoots during their elongation. This study was made with the hybrid walnut $J$. nigra $x J$. regia 34 . 


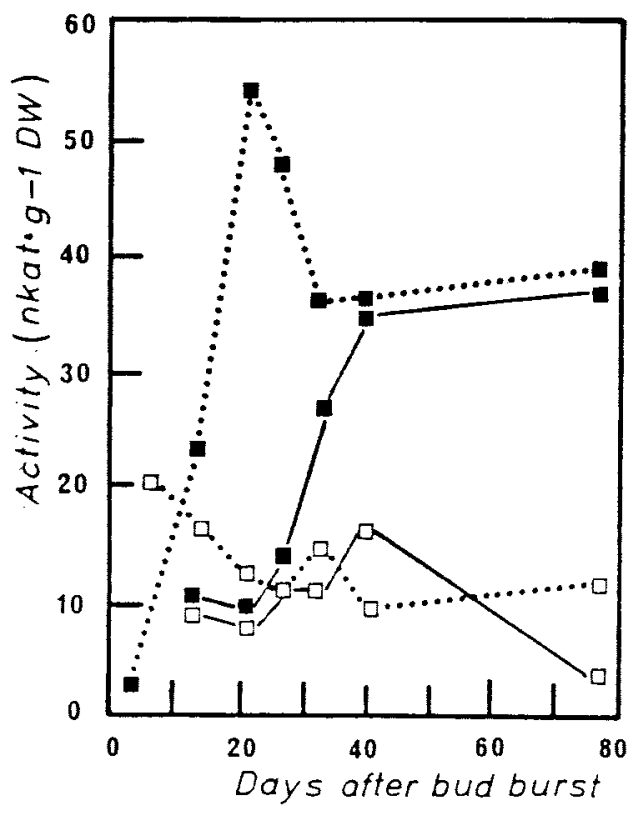

Fig. 3. Evolution of enzyme activity in adult (...) and rejuvenated ( - ) shoots during the growth period of the hybrid walnut $J$. nigra $\times J$. regia 31 . GDH (J) and

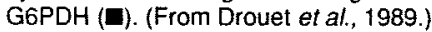

\section{Discussion}

Ageing and rejuvenation of walnut trees has been characterized by different biochemical factors. In addition, studies undertaken on Prunus avium showed an increase of different flavonoids in phloem with ageing (Treutter et al., 1987). Moreover, Zimmerman et al. (1985) reported changes of enzyme activities (ribonuclease, phosphatase, phenolase) during the different stages of development of woody plants. Recently, a specific protein of cell walls has been found to be associated with juvenility of Sequoia sempervirens (Bon, 1988).

All these data suggest that biochemical characteristics of ageing and rejuvenation could be related to root effects, tissue quality and gene activation.
In walnut, the accumulation of phenolic compounds ( $A$ and $B$ ) was not directly controlled by PAL activity. This enzyme was linked to growth acceleration (results not published) and involved in lignification processes, while compound A decreased steadily and compound $B$ remained stable when the elongation rate increased during the first growth period of stump sprouts.

On the other hand, the initiation of growth and its acceleration seem to be linked to enzyme changes (GDH and G6PDH). Protein content decreased because of the synthesis of non-protein substances during growth (mainly lignin). Correlatively, activities of G6PDH (pentose phosphate pathway) and GDH (cellular detoxification of $\mathrm{NH}_{4}^{+}$) increased and ensured, respectively, the production of NADPH and NADH which are needed for active growth (Drouet et al., 1989).

The identification of the structure of the phenolic compounds associated with rejuvenation and their enzymatic regulation (PAL and chalcone synthetase) remains a high priority. It will also be necessary to specify relationships between typical phenolic compounds, their metabolism, growth and rooting.

\section{References}

Bon M.C. (1988) Aspects biochimiques du clonage de sequoias géants (Sequoiadendron giganteum Buchloz) jeunes et âgés. Ph.D. Thesis, Université Clermont-Ferrand II, France

Bonga J.M. (1982) Vegetative propagation in relation to juvenility, maturity and rejuvenation. In: Tissue Culture in Forestry. (Bonga J.M. \& Durzan D.J., eds.), Martinus Nijhoff, Boston, pp. $387-412$

Cornu D. (1977) La multiplication végétative du noyer hybride. Résultats d'une première campagne. Perspectives d'avenir. Rev. Fr. For. Tech. For. 29, 457-463

Drouet A., Weiswald N., Jay-Allemand C. \& Cornu D. (1989) Pentose phosphate pathway and glutamate dehydrogenase activities in adult 
and rejuvenated hybrid walnut trees. Plant Physiol. Biocherm. 27, 259-267

Jay-Allemand C., Cornu D. \& Macheix J.J. (1987) Caractérisation de la rejuvénilisation du noyer (Juglans sp.) par une étude spectrophotométrique globale du contenu polyphénolique. Ann. Sci. For. 44, 303-304

Jay-Allemand C., Cornu D. \& Macheix J.J. (1988) Biochemical attributes associated with rejuvenation of walnut tree. Plant Physiol. Biochem. 26, 139-144
Treutter D., Feucht W. \& Schmid P.P.S. (1987) Ageing-dependent responses of phloem flavonids of Prunus avium graftings: flavanone-, flavone- and isoflavone-glycosides. Sci. Hortic., 32, 183-193

Zimmerman R.H., Hackett W.P. \& Pharis R.P. (1985) Hormonal aspects of phase changes and precocious flowering in hormonal regulation of development III. In: Encyclopedia of Plant Physiology New Series, 11 (Pharis R.P. \& Reid D.M., eds.), Springer-Verlag, Berlin. pp. 79-115 